\title{
Habilitáltak publikációs adatainak vizsgálata többváltozós statisztikai módszerekkel
}

\section{Dobos Imre*}

DSc, a Budapesti Corvinus Egyetem egyetemi tanára

E-mail: imre.dobos@unicorvinus.hu

\section{Michalkó Gábor}

DSc, a Budapesti Corvinus Egyetem egyetemi tanára, az MTA Csillagászati és Földtudományi Kutatóközpont Földrajztudományi Intézet tudományos tanácsadója

E-mail: gabor.michalko@unicorvinus.hu

\section{Novóky Grzsébet}

DSc, a Budapesti Corvinus Egyetem professor emeritája E-mail: erzsebet.novaky@unicorvinus.hu
A Budapesti Corvinus Egyetem Doktori Tanácsa 2015 tavaszán felkért egy munkabizottságot, hogy tegyen javaslatot az intézményben müködő hét társadalomtudományi doktori iskola egységes habilitációs követelményei publikációs és hivatkozási kritériumainak meghatározására. A munkabizottság tagjait képviselő szerzők jelen tanulmányukban egy közel 12 hónapon keresztül tartó kutatást mutatnak be, amely a többváltozós matematikai statisztika módszertanának segítségével kívánt eleget tenni az egyetemi testület felkérésének. A tanulmányban végigkövethetők a kutatás legfontosabb mozzanatai, különösen a matematikai statisztikára épülő vizsgálatok. A szerzők három különböző adatállománnyal elvégzett vizsgálat eredményeit mutatják be. Az alkalmazott módszerek két kérdésre keresték a választ: egyrészt, hogy mely változók (teljesítménymutatók) jellemzik az adatállományt, másrészt, hogy a habilitáltak milyen csoportba oszthatók.

TÁRGYSZÓ:

Faktoranalízis.

Klaszterelemzés.

Többdimenziós skálázás.

DOI: 10.20311/stat2017.07.hu0669

* A szerző köszönetét fejezi ki a Dortmundi Műszaki Egyetem (Németország) Gambrinus Fellowship Programme-jának támogatásáért. 


\begin{abstract}
A természet- és a társadalomtudományok évezredes szimbiózisának egyik szemléletes példája a matematika segítségül hívása a különböző közösségek problémáinak megoldására (Sain [1986]). Az egyiptomiak a Nílus áradásának várható időpontját (Kákosy-Varga [1970]), a nagy földrajzi felfedezésben érintettek a végeláthatatlan távolságokat (Grimbly [2002]), az ipari forradalom korának feltalálói a gépeket meghajtó erő nagyságát (Landes [1986]) óhajtották a lehető legpontosabban meghatározni. A modern kor társadalma már nem elégedett a termeléshez vezető út matematikai eszközökkel történő kijelöléséhez, a teljesítmény mérése, összehasonlítása kulcsfontosságúvá vált (Samuelson-Nordhaus [2012]). Mivel a XX. század második felére a tudomány meghatározó termelési tényezővé vált, a matematika a tudósok teljesítményének értékelésébe is beszürödött (Glänzel [2009]). Mára a tudománymetria diszciplínává vált, mühelyek, iskolák tucatjai igyekeznek az általuk kidolgozott mutatót elfogadtatni (Vinkler [2008]). A legnagyobb kihívást azonban az összehasonlítás igénye jelenti. Képesek-e a matematikusok módszertani arzenáljának felhasználásával megalkotott képletek generális megoldást nyújtani? Egyes tudományterületek képviselői nyertesnek, másoké vesztesnek érzik magukat, utóbbiak mumusként tekintenek az impakt faktorban, a $h$ - és a $g$-indexben megtestesülő mérésekre (Csaba-Szentes-Zalai [2014]). A tudományok atomizálódása jelentős kihívás elé állította a scientometria elkötelezettjeit, és egyre nagyobb teret adott a szkeptikus hangoknak (Bencze [2014]), amelyek lényege így fogalmazható meg: hogyan lehetne az almát a körtével összehasonlítani, amikor mindkettőből több tucat fajta létezik? A tudomány immáron nem csupán hobbi, hanem megélhetést biztosító professzionális tevékenység, olyan piaci tényező, amelynek magasztos égisze alatt az egyének és a kutatói közösségek egymással a kedvezőbb egzisztenciális pozíciókért versenyeznek. A mérés tehát megkerülhetetlen, mikéntjének kidolgozása egy olyan mindennapi eljárás során is, mint a habilitáció, hosszú hónapokig tartó, jelentős szellemi kapacitásokat lefoglaló és felemésztő feladat.

A habilitáció az egyetemi tanárrá válás útjának egyik meghatározó állomása. A porosz eredetű eljárást már a királyi Magyarország egyetemein is alkalmazták, azonban a tudományos élet szovjet típusú átalakítása során teljes mértékben kiiktatták a rendszerböl, amelyet csak az 1993-ban elfogadott felsőoktatási törvény állított vissza (Berényi [1995]). A kizárólag doktori iskolá(ka)t müködtető egyetemeken lefolytatható habilitációs eljárás lényege az előadói készség és az elért tudományos teljesítmény értékelése. Az utóbbi kritériummal kapcsolatban azonban viszonylag hamar felszínre kerültek és állandósultak az anomáliákat hangsúlyozó kritikai észrevételek (Hamza [2014]). Ezek fókuszában az egyetemek hatáskörébe utalt, jobbára autonóm módon meghatározható, ennél fogva intézményenként érzékelhető színvonalbeli különbségeket eredményező eljárások álltak (Patkós [2003], Papp [2005]). A kritikus pont a publikációs elvárások
\end{abstract}


és azok teljesítése volt, egyes intézmények nemzetközi mércét alkalmaztak, mások azonban nem tették ilyen magasra a lécet. Idővel a döntéshozók is szembesültek a rendszer tarthatatlanságával, és jogszabályalkotás ${ }^{1}$ révén igyekeztek a kiegyenlítettebb elvárások felé terelni az egyetemek illetékes testületeit.

A BCE (Budapesti Corvinus Egyetem) Doktori Tanácsa is felismerte, hogy a professzori korba érő generáció „habilitációs nyomásának” egységes mederben tartása érdekében elkerülhetetlen a habilitációs kritériumrendszeren belül a tudományos teljesítmény mutatóinak explicit és az érintett tudományágak közötti konszenzusos meghatározása. A doktori képzés irányítótestülete 2015 tavaszán felkért egy, a jelen tanulmány szerzőivel egyező, háromtagú munkabizottságot, hogy tegyen javaslatot a habilitáció publikációs kritériumaira. A munkabizottság abból indult ki, hogy a társadalomtudományok területén, az egyetemen habilitáltaknak az MTMT-ben (Magyar Tudományos Mủvek Tára) fellelhető publikációit veszi alapul, és az egyetemi könyvtár dolgozóinak közremüködésével két adatbázist képez belőle: az egyik a habilitáció évéig megjelent, a másik a teljes életmüvet átfogó tudományos közleményeket tartalmazza. A munka ettől a fázistól kezdődően átlépett a többváltozós matematikai statisztika világába, mert arra a kérdésre kellett válaszolni, milyen módszerrel jelölhető ki az a követelményrendszer, amelyet a jövőben habilitálni óhajtóknak teljesíteniük kell.

Jelen tanulmányunk a matematikai statisztika eszköztárának felhasználásával igyekszik egy viszonylag egyszerü tudománymetriai kihívásnak eleget tenni, történetesen meghatározni azt az eljárást, amellyel a korábban habilitáltak publikációs adataiból kinyerhetők a jövőben habilitálni óhajtókkal szembeni számszerủ elvárások. Azt a háromkörös folyamatot mutatjuk be, amely a munkabizottság egyes elöterjesztéseinek vizsgálatokkal történő megalapozását és az illetékes döntéshozók állásfoglalását tükrözi. A fejezetek az egymásra épülő fázisokban elvégzett feladatokat és a döntéshozói reflexiókat tartalmazzák. Vizsgálatunk során az optimális megoldást keressük, de a tudományos minősítésben az elmúlt évtizedekben szerzett saját tapasztalataink és a tudománymetriai szakirodalomban (Braun [2008], Zsoldos [2015]) megfogalmazottak alapján feltételezzük, hogy ilyen nem létezik, ezért számításaink elsősorban ajánlások megfogalmazására alkalmasak.

A vizsgálatba bevont adatállományok a BCE döntéshozó testületeinek véleményét tükrözve alakultak ki. A háromféle elemzés alapját az MTMT-ből elérhető információk képezték. Az MTMT-adatbázisból minden kutatóra/oktatóra két táblázat nyerhető ki: az általános (összefoglaló) táblázat, amelyet az MTMT rendszere mindig, automatikusan, külön beállítás nélkül generál a felvitt adatokból; és egy akadémiai osztályt jellemző, esetünkben az MTA IX. Osztályának, azaz a tudományterület táblázatát, amit a publikációs adatokat felvivő kutatónak magának kell beállítania, mert azt különben más nem látja. Az első vizsgálatba azok az MTMT-ben szereplő

1387/2012. (XII. 19.) Korm. rendelet a doktori iskolákról, a doktori eljárások rendjéről és a habilitációról. 
adatok kerültek, amelyek az áttekintő (összefoglaló) táblázatokból szabadon hozzáférhetők voltak (1. adatbázis), vagyis a habilitáltak adatait az akkori állapotig, esetünkben 2015. június 30-ig tartalmazták. Az Egyetemi Doktori Tanács kritikáját figyelembe véve - az egyetemi könyvtár munkatársainak ${ }^{2}$ segítségével - alakította ki a munkabizottság a következő két adatállományt, amely a még aktív habilitáltak adatait az áttekintő (összefoglaló) (2. adatbázis) és az MTA IX. Osztály táblázatai alapján (3. adatbázis), de már csak a habilitálás évéig bezárólag tartalmazta. Azért volt szükségünk az egyetemi könyvtár munkatársainak segítségére, mert ők rendelkeznek azzal a technikai és tudásbeli képességgel, hogy minden olyan egyetemi munkatárs MTMT-beli adataihoz hozzáférnek, akik az egyetem alkalmazásában vannak. Ez azt jelenti, hogy a könyvtár munkatársai elő tudták állítani a táblázatokat az MTMT adatbázisából minden oktatóra/kutatóra a habilitáció évével bezárólag, míg a bizottság tagjai csak a pillanatnyi, aktuális adatokat érhették el. Dolgozatunkban e három adatállomány többváltozós matematikai-statisztikai elemzését adjuk közre. Munkánk szorosan kapcsolódik a Magyar Tudományban 2016 novemberében megjelent dolgozathoz (Dobos-Michalkó-Nováky [2016]), amelyben a döntési folyamatot és a javaslataink kritikáját mutattuk be. Mivel ott nem tértünk ki a statisztikai modelljeink felvázolására és kritikai elemzésére, ezért itt ezeket állítjuk előtérbe.

A többváltozós statisztikai modelleket arra használtuk, hogy az adatbázis alapján, az átlagok segítségével számszerü követelményeket fogalmazzunk meg, valamint azt vizsgáljuk, hogy az aktív habilitáltak adatai - mint egy öntanuló adatbázis hogyan reagálnak a javasolt minimum követelményekre. A korrelációelemzés és a faktoranalízis segítségével arra a kérdésre kerestük a választ, hogy mely változók jellemzik, illetve tömörítik a változók közötti kapcsolatokat, míg a klaszteranalízist és a többdimenziós skálázást a nagyon kiemelkedő, föleg nemzetközi teljesítményt nyújtó habilitáltak kiválasztására alkalmaztuk. Az utóbbiak elhagyásával nyert adatbázisokat vettük alapul a minimumkövetelmények megállapítására.

\section{A habilitáltak adatainak első, összevont adatbázison történt elemzése}

Az első vizsgálatot 2015 júniusa és augusztusa között végeztük azzal a céllal, hogy a BCE akkor még Társadalomtudományi Doktori Tanácsának Habilitációs Szabályzatából hiányzó habilitációs minimumkövetelmények publikációs részéhez

\footnotetext{
${ }^{2}$ A szerzők ezúton is köszönetet mondanak a BCE Könyvtár munkatársainak: Bavalicsné Kerekes Beátának, Horváth Alexandrának, Lukácsné Varga Juditnak és Tóth Juditnak, hogy az adatokat az MTMT-böl az általunk kért formátumban és a habilitálás évéig bezárólag kigyüjtötték.
}

Statisztikai Szemle, 95. évfolỵam 7. szóm 
számszerü elvárásokat fogalmazzunk meg. A vizsgálat eredményeit a 2015. októberi Egyetemi Doktori Tanács ülésére egy előterjesztéssel együtt állítottuk össze. Ehhez a nyilvánosan rendelkezésre álló MTMT adatbázis szolgált alapul.

A BCE és jogelődei társadalomtudományi karain 1993-tól, vagyis a habilitáció bevezetésétől 2015. június 30-ig összesen 121 oktató/kutató habilitált. A habilitáltak gyakoriságát a 1. ábra szemlélteti. Az egyetemhez aktív oktatóként és/vagy óraadóként a vizsgálat idején is kötődő és életben levő 55 kolléga adatait elemeztük. Az aktív, de már nyugdíjazott habilitáltakat és/vagy professor emeritus/emerita egyetemi tanárokat nem vettük be az adatbázisunkba. Mivel több kolléga nem tette nyilvánossá az MTA IX. Osztályához kapcsolódó táblázatait az MTMT-ben, ezért csak a szabadon elérhetö, összefoglaló (általános) táblázat adatait vettük figyelembe ebben a kutatási fázisban. Tekintettel arra, hogy az elérhető adatokat nem tudtuk a habilitálás évéig visszakövetni, ezért a 2015. június végéig rendelkezésre álló adatokat használtuk a vizsgálatainkhoz. A csoportosítás a következő adatok száma szerint történt:

- nemzetközi szakfolyóiratban és hazai kiadású szakfolyóiratban idegen nyelven megjelent cikkek;

- a független hivatkozások minden megjelent folyóiratcikkre (nemzetközi és hazai kiadású szakfolyóiratban idegen nyelven és hazai kiadású szakfolyóiratban magyar nyelven megjelent cikkekre);

- az összes többi tudományos közleményre kapott hivatkozások.

1. ábra. A BCE társadalomtudományi karokon habilitáltak és a közülük aktivak idöbeli eloszlása, 1993-2015

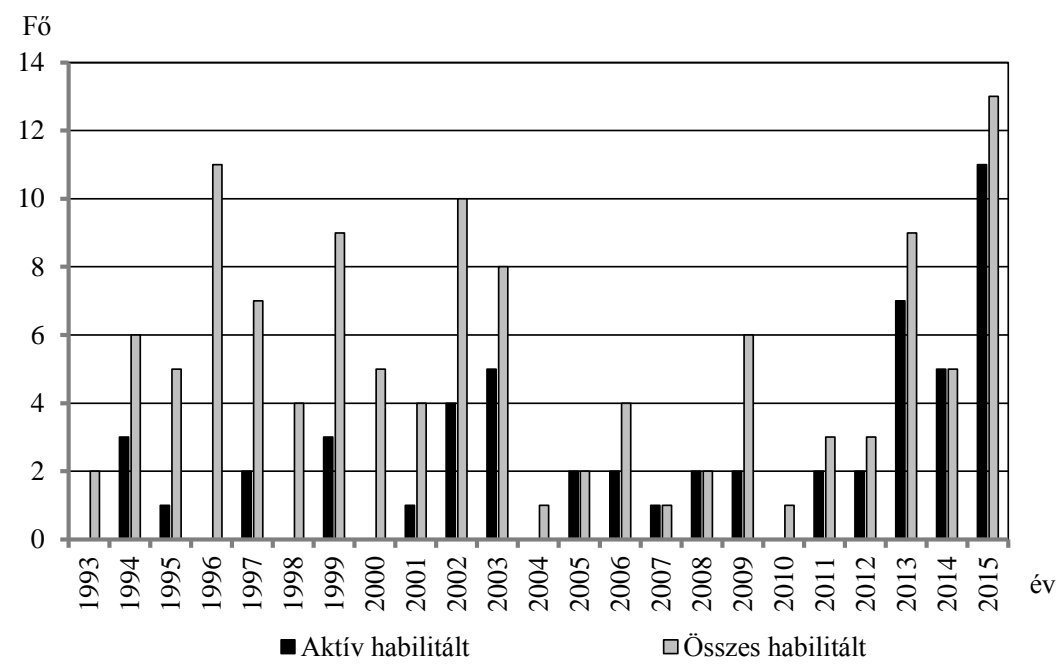

Forrás: Dobos-Michalkó-Nováky [2016]. 
Azért került sor ezeknek az adatköröknek a használatára, mert ezek tekinthetök a tudományos eredményesség alapvető mérőszámainak. Természetesen tisztában voltunk azzal, hogy esetlegesség is lehet ezekben a mutatókban, de első megközelítésben ezt az adatbázist kielégítőnek találtuk a publikációs teljesítmény komplex és összemérhető értékeléséhez.

Az 1. táblázat az első vizsgálatba felvett, általunk konstruált változók alapstatisztikáit, azaz átlagát, szórását és relatív szórását mutatja. Ez utóbbi az átlagtól való átlagos relatív eltérés százalékos értékben kifejezve. Esetünkben ez a szám elég nagy, vagyis az adataink széles skálán szórtak. A változóink eloszlásának tesztelésétől eltekintettünk, mert az általunk kitüzött feladathoz annak ismeretére nem volt szükségünk.

1. táblázat

A BCE társadalomtudományi karokon habilitáltak publikációinak, hivatkozásainak alapstatisztikai mutatói az elsö vizsgálatban

\begin{tabular}{l|r|r|c}
\hline \multicolumn{1}{c|}{ Változó } & \multicolumn{1}{c|}{ Átlag } & \multicolumn{1}{c|}{ Szórás } & Relatív szórás (\%) \\
\hline Idegen nyelvü folyóiratcikk & 11,6 & 12,73 & 108,9 \\
\hline Cikkhivatkozás & 98,8 & 140,52 & 142,2 \\
\hline Egyéb tudományos hivatkozás & 84,2 & 101,01 & 120,0 \\
\hline
\end{tabular}

Első vizsgálatunkban egy egyszerü korrelációelemzést végeztünk el az adatokra, azaz a változókra a habilitálás évével kiegészítve. A korrelációs mátrixot a 2. táblázat mutatja, melyből kiderül, hogy a három változó közötti kapcsolat közepesen erős.

2. táblázat

\begin{tabular}{l|c|c|c|c}
\multicolumn{5}{c}{ A változók korrelációs mátrixa az első vizsgálatban } \\
\hline \multicolumn{1}{c|}{ Változó } & Habilitálás éve & $\begin{array}{c}\text { Idegen nyelvủ } \\
\text { folyóiratcikk }\end{array}$ & Cikkhivatkozás & $\begin{array}{c}\text { Egyéb tudományos } \\
\text { hivatkozás }\end{array}$ \\
\hline Habilitálás éve & 1 & $-0,327$ & $-0,032$ & $-0,244$ \\
\hline Idegen nyelvü folyóiratcikk & $-0,327$ & 1 & 0,634 & 0,553 \\
\hline Cikkhivatkozás & $-0,032$ & 0,634 & 1 & 0,418 \\
\hline Egyéb tudományos hivatkozás & $-0,244$ & 0,553 & 0,418 & 1 \\
\hline
\end{tabular}

Nem mutatható ki korrelációs kapcsolat a változók és a habilitálás éve között, eltekintve az idegen nyelvü cikkek számától. Ez azt jelenti, hogy a folyóiratcikkekre és az összes többi közleményre kapott hivatkozások száma lineárisan nincs, illetve csak 
gyenge kapcsolatban van a habilitáció évével. Ellenben az idegen nyelvü folyóiratcikkek száma gyenge közepes negatív korrelációt mutat a habilitálás évével, ami arra utal, hogy minél korábban habilitált valaki, valószínűleg annál kevesebb idegen nyelvü cikket publikált. (A statisztikai számításainkat az SPSS 22 statisztikai programcsomagjával hajtottuk végre.)

Ezt követően azt vizsgáltuk meg, hogy ebben az adatbázisban a három változó a habilitálás évével kiegészítve mennyire jellemzi a megfigyeléseinket. Ehhez a vizsgálathoz faktoranalízist hajtottunk végre (Füstös et al. [1986]). A korrelációs mátrix már jelzi, hogy a három változónk nagy valószínüséggel együtt mozog, míg a habilitálás éve a változóktól független lehet.

A faktoranalízist főkomponens módszerrel, valamint Kaiser-féle varimax rotációval hajtottuk végre. A faktorok számát az egynél nagyobb sajátértékek számával azonosítottuk, ami esetünkben kettő volt. Így a variancia 78,9 százalékát, ebből az első faktor a szórás 51,0 százalékát magyarázza. A 3. táblázat a faktorok változókkal mutatott korrelációit ábrázolja. Csak azokat az értékeket mutatjuk be, amelyek az adott faktorral abszolút értékben 0,4-nél magasabb korrelációval rendelkeznek. Igaz, vannak olyan ajánlások is, ahol az 55-ös adatbázisunk esetén mintegy 0,7-es korrelációt javasolnak. A táblázat azt is mutatja, hogy amíg három publikációs változó egy faktorba került, addig a habilitálás éve egy azzal nem korreláló faktort ad.

3. táblázat

\begin{tabular}{l|c|c}
\multicolumn{2}{c}{ Rotált faktorok mátrixa az elsö vizsgálatban } \\
\hline \multirow{2}{*}{ Változó } & \multicolumn{2}{c}{ Faktor } \\
\cline { 2 - 3 } & 1 & 2 \\
\hline Cikkhivatkozás & 0,879 & \\
\hline Idegen nyelvű folyóiratcikk & 0,853 & \\
\hline Egyéb tudományos hivatkozás & 0,727 & \\
\hline Habilitálás éve & & 0,966 \\
\hline
\end{tabular}

Az adatbázisunk korrelációs struktúráját ezzel feltártuk. Ezután arra kíséreltünk meg választ kapni, hogy milyen csoportok képezhetők a megfigyeléseink, azaz a habilitáltak között. Ezt a klaszteranalízis és a többdimenziós skálázás módszereinek segítségével végeztük el a változóinkra és a habilitálás évére. A két módszer kapcsán arra voltunk kíváncsiak, hogy azok azonos eredményt adnak-e.

$\mathrm{Az}$ alkalmazott hierarchikus klaszteranalízisnél a csoportba osztáshoz a dendrogramok adtak segítséget. Az euklideszi távolságmértéket választottuk, míg a csoportképzés alapja a csoporton belüli kapcsolat volt. 
2. ábra. Az összevont adatbázis egyedeinek csoportositása az első vizsgálatban

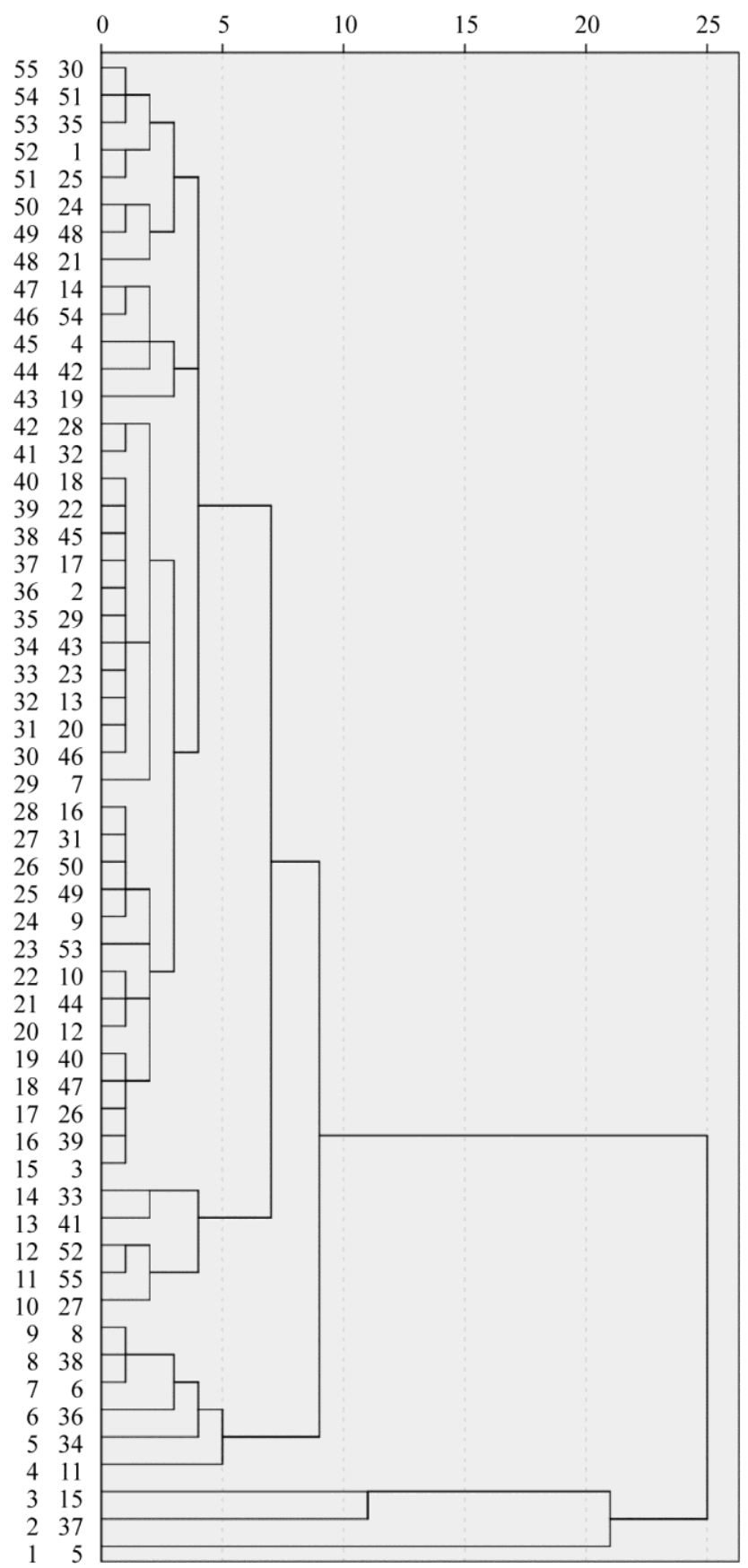

Statisztikai Szemle, 95. évfolụam 7. szóm 
A dendrogramot a 2. ábra szemlélteti. A vizsgálat alapján négy csoportot sikerült elkülönítenünk (a csoportok átlagát és szórását a Dobos-Michalkó-Nováky [2016] dolgozat tartalmazza a további vizsgálatainkban is, ezért annak közlésétől itt eltekintünk):

1. Egy 3 fös csoport, amelynek tagjai (az 5, 15 és 37-es számú habilitált) a legtöbb idegen nyelvü publikációval és az összes folyóiratcikkre adott nagyszámú hivatkozással rendelkeznek.

2. A következő csoportba 6 (a 6, 8, 11, 34, 36 és 38-as számú) habilitált került, akiknek föként az egyéb hivatkozásaik száma magas.

3. A harmadik csoportot 5 (a 27, 33, 41, 52 és 55-ös számú), többnyire fiatal habilitáltak alkotják, akik számos idegen nyelvü publikációval és az összes folyóiratcikkekre adott viszonylag magas számú hivatkozással rendelkeznek.

4. Az utolsó, tovább nem csoportosítható egységbe 41 habilitált került.

Meg kell jegyeznünk, hogy a csoportok kialakításánál az 5, 15 és 37-es számú habilitáltakat - amint a dendrogram is mutatja - le kellett választanunk, mert ha ezek az adatállományban maradnak, akkor a négy klaszter közül három darab 1 elemes és egy 52 elemes lett volna.

A többdimenziós skálázáshoz az SPSS ALSCAL programját választottuk. Mivel csak négy változót tartalmaz az adatbázisunk, ezért bátran alkalmaztuk a négydimenziós térből a kétdimenziósba történő áttérést. Ezt a 3. ábra mutatja.

3. ábra. A többdimenziós skálázás eredménye az összevont adatbázis alapján az első vizsgálatban

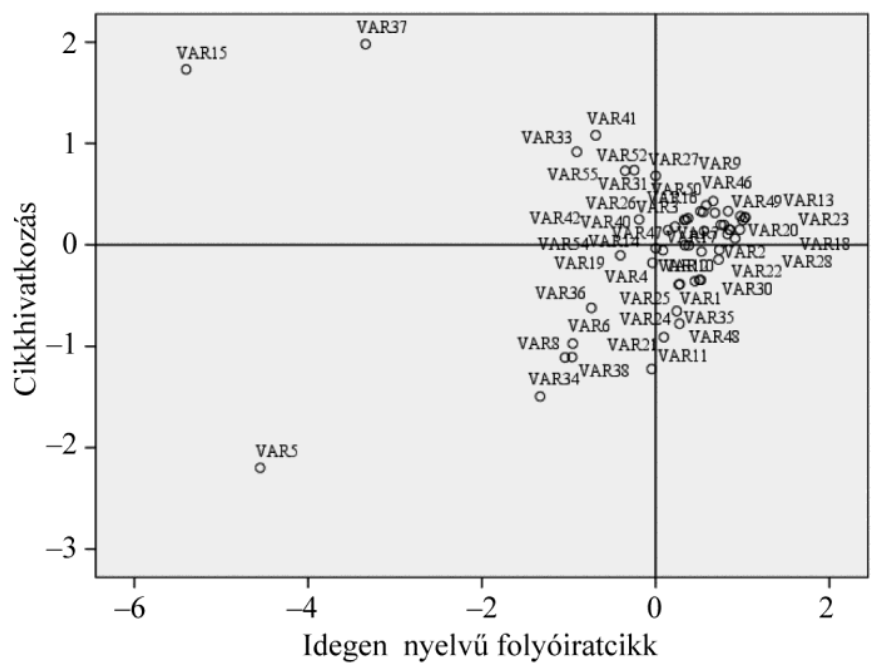

Statisztikai Szemle, 95. évfolụam 7. szóm 
A módszerrel nyert eredmény nagyon jól leképezi a négydimenziós térből a síkra a habilitáltak közötti távolságokat. Az egyezés mértéke, vagyis az $R^{2}$ értéke 0,99988 . A stresszérték is alacsony: 0,00813.

A „térkép” alapján vizuálisan is igazolhatjuk, hogy a klaszterelemzés és a többdimenziós skálázás azonos eredményeket adott, azt nem ismételjük meg. Ezzel az összevont adatokra elvégzett vizsgálatainkat befejeztük.

\section{A habilitáltak adatainak elemzése az összefoglaló (általános) táblázat alapján a habilitálás évéig bezárólag}

Az előbbiekben bemutatott elemzésünkkel szemben az egyetem társadalomtudományi doktori iskolái vezetőinek legélesebb kritikája az volt, hogy az adatbázis a habilitáltak publikációs adatait az adatgyüjtés időpontjáig, azaz 2015. június 30ig, és nem a habilitálás évéig tartalmazta. Elfogadva a jogos kritikát, a második vizsgálatunkban a habilitálás évéig nyújtott tudományos teljesítményt vettük alapul mind az 55 habilitáltra. Az adatokat az MTMT-adatbázisból az egyetemi könyvtár munkatársainak segítségével gyűjtöttük ki. Kérésünk az volt, hogy az új adatbázis tartalmazza a publikációk MTA IX. Osztályának táblázatát és az MTMT-ben automatikusan generált, akkor még ,általános (összefoglaló) táblázat” szerinti csoportosítást is az adott időpontig, azaz 2015. november 22-ig. Vizsgálatainkat az általános táblázat adataira mutatjuk be elöször. Az új adatbázisunkba immár nyolc változót vonhattunk be:

- a tudományos folyóiratcikkek csoportjait:

- a nemzetközi szakfolyóiratcikkeket és hivatkozásaikat;

- a hazai kiadású, idegen nyelvü szakfolyóiratcikkeket és hivat-

kozásaikat;

- a hazai kiadású, magyar nyelvủ szakfolyóiratcikkeket;

- összegezve a könyv; könyvrészlet; konferenciakötetben megje-

lent teljes előadásszöveg és az azokra kapott hivatkozások számát.

Az adatok alapstatisztikai tulajdonságait a 4. táblázatban foglaltuk össze.

Elöször az új adatállomány korrelációs elemzését végeztük el. A nyolc változót ismételten kiegészítettük a habilitáció évével. Az eredményeket az 5. táblázatban mutatjuk be. 


\section{4. táblázat}

A BCE társadalomtudományi karokon habilitáltak publikációinak, hivatkozásainak alapstatisztikai mutatói a második vizsgálatban

\begin{tabular}{l|r|r|r}
\hline \multicolumn{1}{c|}{ Változó } & \multicolumn{1}{c|}{ Átlag } & \multicolumn{1}{c}{ Szórás } & Relatív szórás (\%) \\
\hline nki cikk & 6,2 & 6,97 & 112,4 \\
\hline nki cit & 41,6 & 84,06 & 202,3 \\
\hline hi cikk & 1,8 & 1,74 & 99,8 \\
\hline hi cit & 1,8 & 3,95 & 224,4 \\
\hline hm cikk & 15,7 & 10,23 & 65,3 \\
\hline hm cit & 16,1 & 17,53 & 108,8 \\
\hline II. + III. + IV. & 34,5 & 25,38 & 73,7 \\
\hline II. + III. + IV. cit & 37,8 & 50,95 & 134,8 \\
\hline
\end{tabular}

Megjegyzés. A második vizsgálat változói itt és a továbbiakban I. tudományos folyóiratcikkek csoportjai: nki cikk: nemzetközi folyóiratcikk, nki cit: nemzetközi folyóiratcikk hivatkozása, hi cikk: idegen nyelvü hazai folyóiratcikk, hi cit: idegen nyelvü hazai folyóiratcikk hivatkozása, hm cikk: magyar nyelvü hazai folyóiratcikk, hm cit: magyar nyelvü hazai folyóiratcikk hivatkozása, II.+III.+IV.: könyv+könyvrészlet+konferenciacikk, $I I .+I I I .+I V$. cit: könyv+könyvrészlet+konferenciacikk hivatkozása.

A változók korrelációs mátrixa a második vizsgálatban

\begin{tabular}{|c|c|c|c|c|c|c|c|c|c|}
\hline Változó & $\begin{array}{c}\text { Habilitáció } \\
\text { éve }\end{array}$ & nki cikk & nki cit & hi cikk & hi cit & hm cikk & hm cit & $I I .+I I I .+I V$. & $\begin{array}{c}I I .+I I I .+I V . \\
\text { cit }\end{array}$ \\
\hline Habilitáció éve & 1 & $-0,061$ & 0,306 & $-0,037$ & 0,055 & $-0,142$ & 0,182 & 0,359 & 0,249 \\
\hline nki cikk & $-0,061$ & 1 & 0,524 & 0,199 & 0,029 & 0,466 & 0,106 & 0,300 & 0,194 \\
\hline nki cit & 0,306 & 0,524 & 1 & 0,193 & $-0,007$ & 0,058 & $-0,015$ & 0,386 & 0,116 \\
\hline hi cikk & $-0,037$ & 0,199 & 0,193 & 1 & 0,261 & 0,085 & 0,037 & 0,144 & 0,112 \\
\hline hi cit & 0,055 & 0,029 & $-0,007$ & 0,261 & 1 & 0,003 & 0,010 & $-0,093$ & 0,112 \\
\hline hm cikk & $-0,142$ & 0,466 & 0,058 & 0,085 & 0,003 & 1 & 0,511 & 0,275 & 0,269 \\
\hline$h m$ cit & 0,182 & 0,106 & $-0,015$ & 0,037 & 0,010 & 0,511 & 1 & 0,281 & 0,396 \\
\hline$I I .+I I I .+I V$ & 0,359 & 0,300 & 0,386 & 0,144 & $-0,093$ & 0,275 & 0,281 & 1 & 0,644 \\
\hline$I I .+I I I .+I V$. cit & 0,249 & 0,194 & 0,116 & 0,112 & 0,112 & 0,269 & 0,396 & 0,644 & 1 \\
\hline
\end{tabular}

Az állapítható meg, hogy a habilitáció éve gyengén közepes korrelációt mutat a nemzetközi szakfolyóiratokban megjelent cikkek citációival, valamint a könyvek, könyvrészletek és konferenciakötetben megjelent előadásszövegek együttes számával. Ez azzal magyarázható, hogy egyrészt a hivatkozások megfigyelése is hangsúlyosabbá vált, másrészt az információk áramlása is felgyorsult. A többi változóval 
nem mutat lineáris kapcsolatot a habilitáció éve. Az is megfigyelhető, hogy a folyóirat típusa és az arra kapott citációk száma erős közepes kapcsolatot mutat három esetben. Ez alól csak a hazai idegen nyelvü folyóiratcikkek és a rájuk kapott hivatkozások száma a kivétel. Mindez annak következménye lehet, hogy az ilyen dolgozatok hivatkozásának kultúrája szerényebb előzményekkel rendelkezik. A korrelációknál az is figyelemre méltó, hogy a nemzetközi cikkek száma erős közepes korrelációt mutat a magyar szakfolyóiratban megjelent cikkek számával. Ez azzal magyarázható, hogy aki nemzetközileg is publikál, az nagy valószínüséggel magyarul is.

A következő lépés, amint az előzőkben is, a faktoranalízis végrehajtása volt. A korrelációs mátrix jelzi, hogy az adott folyóirattípusban megjelent publikációk száma nagy valószínűséggel együtt mozog a rá kapott hivatkozások számával. A faktoranalízist ebben az esetben is fökomponens módszerrel, valamint Kaiser-féle varimax rotációval hajtottuk végre. A faktorok számát az egynél nagyobb sajátértékek számával azonosítottuk, ami esetünkben négy volt. A variancia 74,1 százalékát, míg a négy faktor nagyjából azonos varianciát magyaráz: az első 21,5, a második 19,5, a harmadik 18,9, a negyedik 14,2 százalékot mutat. A 6. táblázat a faktorok változókkal mutatott korrelációit közli.

6. táblázat

\begin{tabular}{l|c|c|c|c}
\multicolumn{5}{c}{ Rotált faktorok mátrixa a második vizsgálatban } \\
\hline \multirow{2}{*}{ Változó } & 1 & 2 & 3 & 4 \\
\hline & \multicolumn{4}{c}{ Faktor } \\
\hline hm cikk & 0,814 & & & \\
\hline hm cit & 0,806 & & & \\
\hline II.+III.+IV. cit & 0,588 & & 0,561 & \\
\hline nki cikk & & 0,849 & & \\
\hline nki cit & & 0,811 & & \\
\hline Habilitáció éve & & & 0,853 & \\
\hline II.+III.+IV. & 0,413 & & 0,647 & \\
\hline hi cit & & & & 0,851 \\
\hline hi cikk & & & & 0,720 \\
\hline
\end{tabular}

A faktorok értelmezése a következő lehet. Az első faktorba kerültek a hazai szakfolyóiratban magyarul megjelent cikkek, a könyvek és a könyvrészletek, valamint a konferenciakötetben megjelent elöadásszövegek együttes száma, továbbá a rájuk kapott hivatkozások. A magyar szakfolyóiratban megjelent cikkek számával és a rájuk kapott hivatkozások számával mutatja a faktor a legnagyobb korrelációt. Fogalmazhatunk úgy is, hogy a habilitáltak ebben „erősek”. A nemzetközi 
szakfolyóiratban megjelent cikkek és a rájuk kapott hivatkozás adja a második faktort, míg a harmadikba az első faktorral közepes korrelációt mutató változók, valamint a habilitáció éve, a negyedikbe a hazai idegen nyelvü cikkek és a rájuk kapott hivatkozások kerültek. Ez az utóbbi két változó a variancia kisebb részét magyarázza.

A (hierarchikus) klaszteranalízissel elvégzett vizsgálat eredményeit a 4. ábra szemlélteti. Itt is az euklideszi távolságmértéket választottuk, míg az összevonás a csoporton belüli kapcsolat alapján történt. Ennek megfelelően a habilitáltak három csoportját sikerült elkülönítenünk:

1. Az első 6 fös csoport, amelynek tagjai (az 5, 34, 36, 37, 38 és 48-as számú habilitált) föként magas egyéb hivatkozással rendelkeznek.

2. A második csoportba 7, föként fiatal (a 15, 33, 41, 42, 47, 52 és 55-ös számú) habilitált került, akiknek magas az idegen nyelvú publikációik és az ezekre kapott hivatkozások száma.

3. Az utolsó, tovább nem csoportosítható egységbe 42 habilitált került.

A dendrogram elemzésénél meg kell jegyeznünk, hogy a 37-es számú habilitáltat a következő csoportba tettük, mert annyira kiesett az adatállományból, hogy az egyelemes klasztert alkotott volna. Ezzel az általánosságot nem sértettük meg lényegesen.

A továbbiakban az első vizsgálatunknál alkalmazott módszerhez hasonlóan jó eredménnyel sikerült leképeznünk megfigyeléseinket a kilencdimenziósból kétdimenziós térbe és a habilitáltak közötti távolságokat. Ezt az 5. ábra mutatja. Az egyezés mértéke ebben az esetben is nagyon magas, az $R^{2} 0,99253$, a stresszérték pedig megfelelöen alacsony 0,07016 .

Látható, hogy a klaszterelemzés és a többdimenziós skálázás azonos eredményeket adott, ezért azt nem ismételjük meg. A két koordináta értelmezése is érdekes lehet. Az $x$ tengely az idegen nyelvü citációk számával azonosítható, míg az y tengely a magyar nyelvü hivatkozásoknak feleltethető meg. 
4. ábra. Az összefoglaló táblázat egyedeinek csoportositása a második vizsgálatban

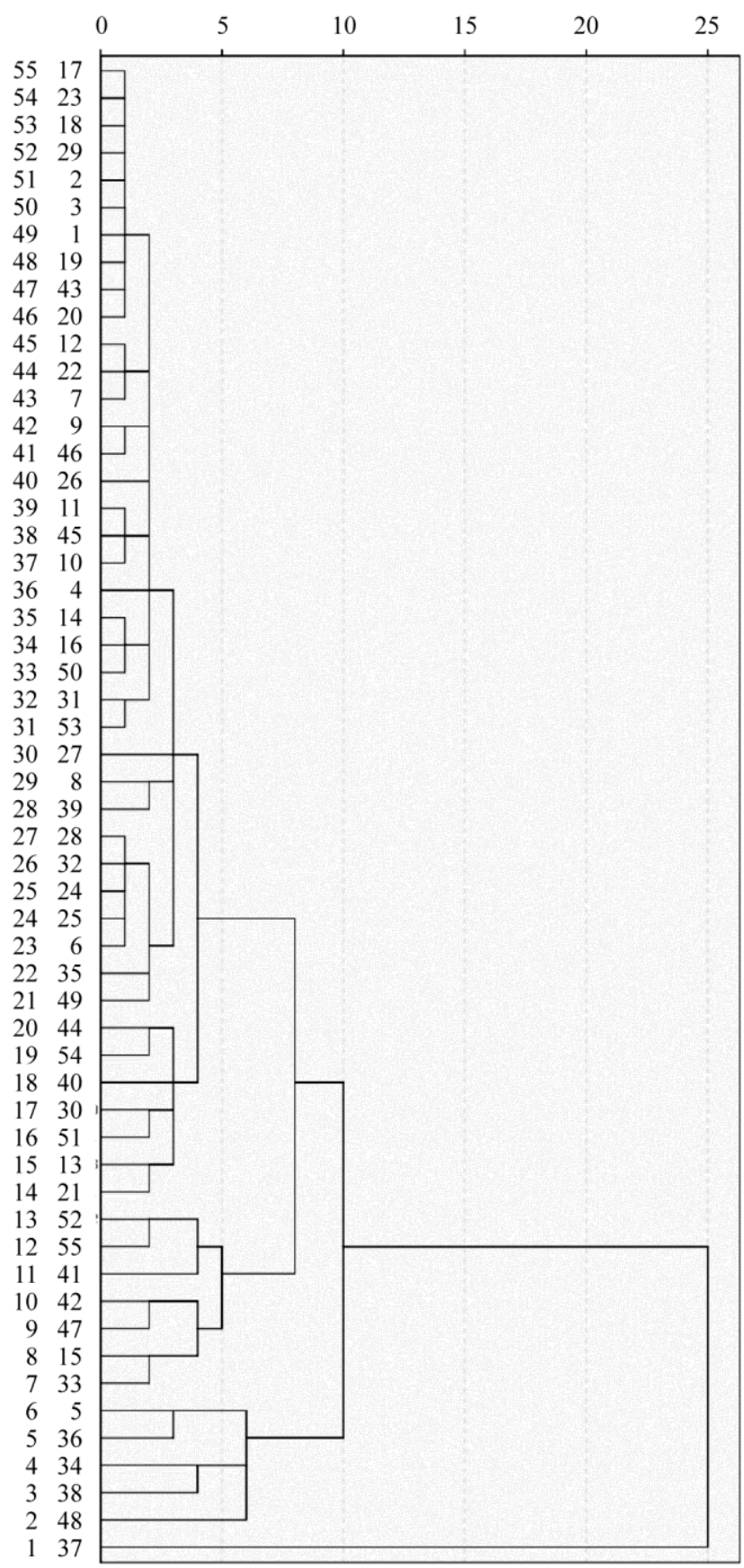


5. ábra. A többdimenziós skálázás eredménye az összefoglaló táblázat adatai alapján a második vizsgálatban

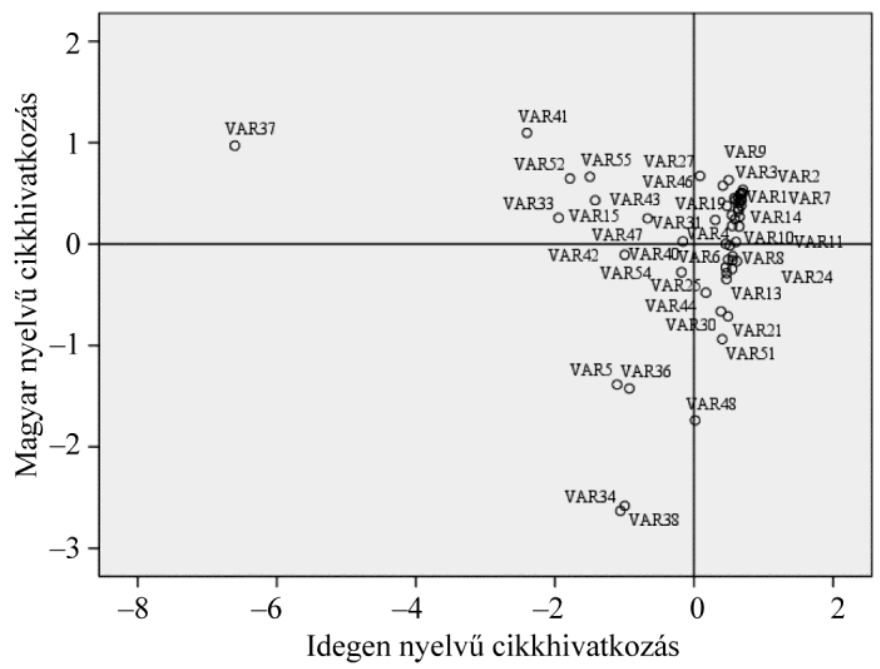

\section{A habilitáltak adatainak elemzése az MTA IX. Osztály táblázata alapján a habilitálás évéig bezárólag}

Az adatokat - amint korábban említettük - az MTMT adatbázisából az egyetemi könyvtár munkatársainak segítségével gyüjtöttük ki. Az új adatbázisunkba most a következő, a IX. Osztály által meghatározott - összesen tíz - változókat vontuk be:

- a tudományos folyóiratcikkek csoportjait:

- a listás idegen nyelvü folyóiratcikkeket és hivatkozásaikat;

- a listás magyar nyelvü folyóiratcikkeket és hivatkozásaikat;

- a nem listás idegen nyelvü cikkeket és hivatkozásaikat;

- a nem listás magyar nyelvű szakfolyóiratcikkeket és hivatkozásaikat;

- összegezve a könyv, könyvrészlet és konferenciakötetben megjelent teljes előadásszöveg és az azokra kapott hivatkozások számát.

Az adatok statisztikai alapjellemzőit a 7. táblázatban foglaltuk össze.

A korrelációs elemzést most is a habilitáció évével kibővített adatállományon végeztük el. Az eredményeket a 8 . táblázatban mutatjuk be. 
A BCE társadalomtudományi karokon habilitáltak publikációnak, hivatkozásainak alapstatisztikai mutatói a harmadik vizsgálatban

\begin{tabular}{l|r|r|r}
\hline \multicolumn{1}{c|}{ Változó } & Átlag & Szórás & Relatív szórás (\%) \\
\hline nkil cikk & 4,4 & 6,17 & 140,3 \\
\hline nkil cit & 37,8 & 83,32 & 220,2 \\
\hline hlist cikk & 15,8 & 11,01 & 69,6 \\
\hline hlist cit & 16,0 & 16,67 & 104,5 \\
\hline nki cikk & 3,4 & 3,99 & 116,0 \\
\hline nki cit & 5,2 & 9,64 & 185,3 \\
\hline h cikk & 5,5 & 5,50 & 100,5 \\
\hline h cit & 2,7 & 5,123 & 194,0 \\
\hline II.+III.+IV. & 27,6 & 21,13 & 76,6 \\
\hline II.+III.+IV. cit & 34,4 & 47,17 & 137,3 \\
\hline
\end{tabular}

Megjegyzés. A harmadik vizsgálat változói itt és a továbbiakban I. tudományos folyóiratcikkek csoportjai: nkil cikk: nemzetközi listás folyóiratcikk, nkil cit: nemzetközi listás folyóiratcikk hivatkozása, hlist cikk: hazai listás folyóiratcikk, hlist cit: hazai listás folyóiratcikk hivatkozása, nki cikk: idegen nyelvủ egyéb tudományos folyóiratcikk, $n k i$ cit: Idegen nyelvű egyéb tudományos folyóiratcikk hivatkozása, $h$ cikk: magyar nyelvủ egyéb tudományos folyóiratcikk, $h$ cit: magyar nyelvü egyéb tudományos folyóiratcikk hivatkozása, $I I .+I I I .+I V$.: könyv+könyvrészlet+konferenciacikk, II.+III. $+I V$. cit: könyv+könyvrészlet+konferenciacikk hivatkozása.

8. táblázat

A változók korrelációs mátrixa a harmadik vizsgálatban

\begin{tabular}{|c|c|c|c|c|c|c|c|c|c|c|c|}
\hline Változó & $\begin{array}{l}\text { Habilitá- } \\
\text { ció éve }\end{array}$ & nkil cikk & nkil cit & $\begin{array}{l}\text { hlist } \\
\text { cikk }\end{array}$ & hlist cit & nki cikk & nki cit & hcikk & h cit & $\begin{array}{l}I I .+I I I .+ \\
\quad+I V .\end{array}$ & $\begin{array}{c}I I .+I I I .+I V . \\
\text { cit }\end{array}$ \\
\hline Habilitáció éve & 1 & $-0,108$ & 0,281 & $-0,148$ & 0,175 & $-0,118$ & 0,168 & 0,101 & 0,211 & 0,399 & 0,287 \\
\hline nkil cikk & $-0,108$ & 1 & 0,589 & 0,417 & 0,001 & 0,412 & 0,095 & 0,203 & 0,011 & 0,158 & 0,014 \\
\hline nkil cit & 0,281 & 0,589 & 1 & 0,039 & $-0,035$ & $-0,019$ & 0,002 & 0,175 & 0,028 & 0,372 & 0,076 \\
\hline hlist cikk & $-0,148$ & 0,417 & 0,039 & 1 & 0,526 & 0,515 & 0,224 & 0,298 & 0,067 & 0,254 & 0,227 \\
\hline hlist cit & 0,175 & 0,001 & $-0,035$ & 0,526 & 1 & 0,209 & 0,334 & 0,231 & 0,436 & 0,290 & 0,390 \\
\hline nki cikk & $-0,118$ & 0,412 & $-0,019$ & 0,515 & 0,209 & 1 & 0,470 & 0,163 & 0,309 & 0,030 & 0,180 \\
\hline nki cit & 0,168 & 0,095 & 0,002 & 0,224 & 0,334 & 0,470 & 1 & 0,187 & 0,509 & 0,105 & 0,340 \\
\hline$h c i k k$ & 0,101 & 0,203 & 0,175 & 0,298 & 0,231 & 0,163 & 0,187 & 1 & 0,213 & 0,561 & 0,372 \\
\hline$h$ cit & 0,211 & 0,011 & 0,028 & 0,067 & 0,436 & 0,309 & 0,509 & 0,213 & 1 & 0,154 & 0,458 \\
\hline$I I .+I I I .+I V$ & 0,399 & 0,158 & 0,372 & 0,254 & 0,290 & 0,030 & 0,105 & 0,561 & 0,154 & 1 & 0,676 \\
\hline$I I .+I I I .+I V$. cit & 0,287 & 0,014 & 0,076 & 0,227 & 0,390 & 0,180 & 0,340 & 0,372 & 0,458 & 0,676 & 1 \\
\hline
\end{tabular}


Az állapítható meg a korrelációkról, hogy a habilitáció éve gyengén közepes korrelációt mutat a nemzetközi szakfolyóiratokban megjelent cikkek citációival, valamint a könyvek, könyvrészletek és konferenciakötetben megjelent előadásszövegek együttes számával és a rájuk kapott hivatkozással. Ez azzal magyarázható, hogy egyrészt a hivatkozások megfigyelése is megnövekedett, másrészt az információk áramlása is felgyorsult, és a habilitáltak több nemzetközi konferenciára is eljuthattak. A többi változóval nem mutat lineáris kapcsolatot a habilitáció éve. Az is megfigyelhető, hogy a folyóirat típusa és az arra kapott citációk száma erős közepes kapcsolatot mutat mind az öt publikációs csoportra nézve. A korrelációknál az is figyelemre méltó, hogy a listás nemzetközi cikkek száma erős közepes korrelációt mutat a listás magyar szakfolyóiratban megjelent cikkek számával. Ez azzal magyarázható, hogy aki nemzetközileg publikál, az nagy valószínüséggel magyarul is.

A korrelációs mátrix már jelzi, hogy az adott folyóirattípusban megjelent publikációk száma nagy valószínüséggel együtt mozog a rá kapott hivatkozások számával. A faktoranalízist ebben az esetben is fökomponens módszerrel, valamint Kaiser-féle varimax rotációval hajtottuk végre. A faktorok számát az egynél nagyobb sajátértékek számával azonosítottuk, ami ebben az esetben is négy volt. A variancia 73,3 százalékát, míg a négy faktor nagyjából azonos varianciát magyaráz: az első 22,4, a második 19,4, a harmadik 16,0, míg a negyedik 15,5 százalékot mutat. A 9. táblázat a faktorok változókkal mutatott korrelációit közli.

9. táblázat

\begin{tabular}{l|c|c|c|c}
\multicolumn{5}{c}{ Votált faktorok mátrixa a második vizsgálatban } \\
\hline & \multicolumn{4}{c}{ Faktor } \\
\cline { 2 - 5 } & 1 & 2 & 3 & 4 \\
\hline II.+III.+IV. & 0,889 & & & \\
\hline II.+III.+IV. cit & 0,734 & & & \\
\hline h cikk & 0,702 & & & \\
\hline hlist cit & 0,520 & 0,438 & & \\
\hline nki cit & & 0,838 & & \\
\hline h cit & & 0,810 & & \\
\hline hlist cikk & 0,407 & & 0,778 & \\
\hline Habilitáció éve & & & $-0,654$ & \\
\hline nki cikk & & 0,571 & 0,599 & \\
\hline nkil cit & & & & 0,878 \\
\hline nkil cikk & & & 0,416 & 0,840 \\
\hline
\end{tabular}

A faktorok értelmezése a következő lehet. Az első faktorba kerültek a hazai nem listás szakfolyóiratban magyarul megjelent cikkek, a hazai listás folyóiratokban meg- 
jelent dolgozatok száma és a rájuk kapott citáció, valamint a könyvek és a könyvrészletek, továbbá a konferenciakötetben megjelent előadásszövegek együttes száma és a rájuk kapott hivatkozások. A könyvek és a könyvrészletek, valamint a konferenciakötetben megjelent elöadásszövegek összegével és a rájuk kapott hivatkozások számával, továbbá a hazai nem listás folyóiratcikkekkel mutatja a faktor a legnagyobb korrelációt. A második faktort a citációkkal ragadhatjuk meg, ugyanis ebbe a komponensbe került a hazai listás szakfolyóiratban megjelent cikkekre kapott hivatkozások száma, valamint a nemzetközi és hazai nem listás folyóiratokban megjelent cikkekre kapott hivatkozások száma. A harmadik faktorba a hazai listás folyóiratcikkek, a nemzetközi nem listás folyóiratcikkek száma, valamint a habilitáció éve, a negyedik, utolsó faktorba a nemzetközi listás idegen nyelvủ cikkek és a rájuk kapott hivatkozások kerültek. Ez a két változó a variancia kisebb részét magyarázza, vagyis ebben a két kategóriában kell a habilitáltaknak javítaniuk.

A (hierarchikus) klaszteranalízissel elvégzett vizsgálat eredményeit a 6. ábra szemlélteti. (Itt is euklideszi távolságot és csoporton belüli kapcsolatokat használtunk modellképzésre.) Ezek alapján a habilitáltak három csoportját különítettük el:

- az első csoportba hatan kerültek, akik föként magas egyéb hivatkozással rendelkeznek $(5,34,36,37,38$ és 48-as számú habilitált),

- a második csoportot hét, föként fiatal habilitált alkotja, akiknek számos idegen nyelvű publikációjuk és az ezekre a cikkekre kapott viszonylag magas számú hivatkozásuk van $(15,33,41,42$, 47, 52 és 55ös számú habilitált),

- végül az utolsó, tovább nem bontható csoport 42 fö́t foglal magába.

A dendrogram elemzésénél a 37-es számú habilitált esetében a 2. fejezetben leírtak szerint jártunk el. A többdimenziós skálázás módszerén sem változtattunk, megvizsgáltuk, hogy a kilencdimenziós térben fekvő megfigyeléseink (habilitáltak) leképezhetők-e a síkra, azaz a kétdimenziós térbe. Ezt az 7. ábra mutatja. Az egyezés mértéke ebben az esetben is magas $\left(R^{2} 0,99311\right)$, a stresszérték is megfelelően alacsony $(0,07175)$.

Itt is megállapítható, hogy a klaszterelemzés és a többdimenziós skálázás szinte teljesen azonos eredményekhez vezet, ezért azt itt már nem ismételjük meg. Mindez arra is rámutat, hogy a két legutóbbi adatállománnyal végzett vizsgálat érdemben nem ad más megoldást. 
6. ábra. Az MTA IX. Osztály táblázata egyedeinek csoportositása a harmadik vizsgálatban

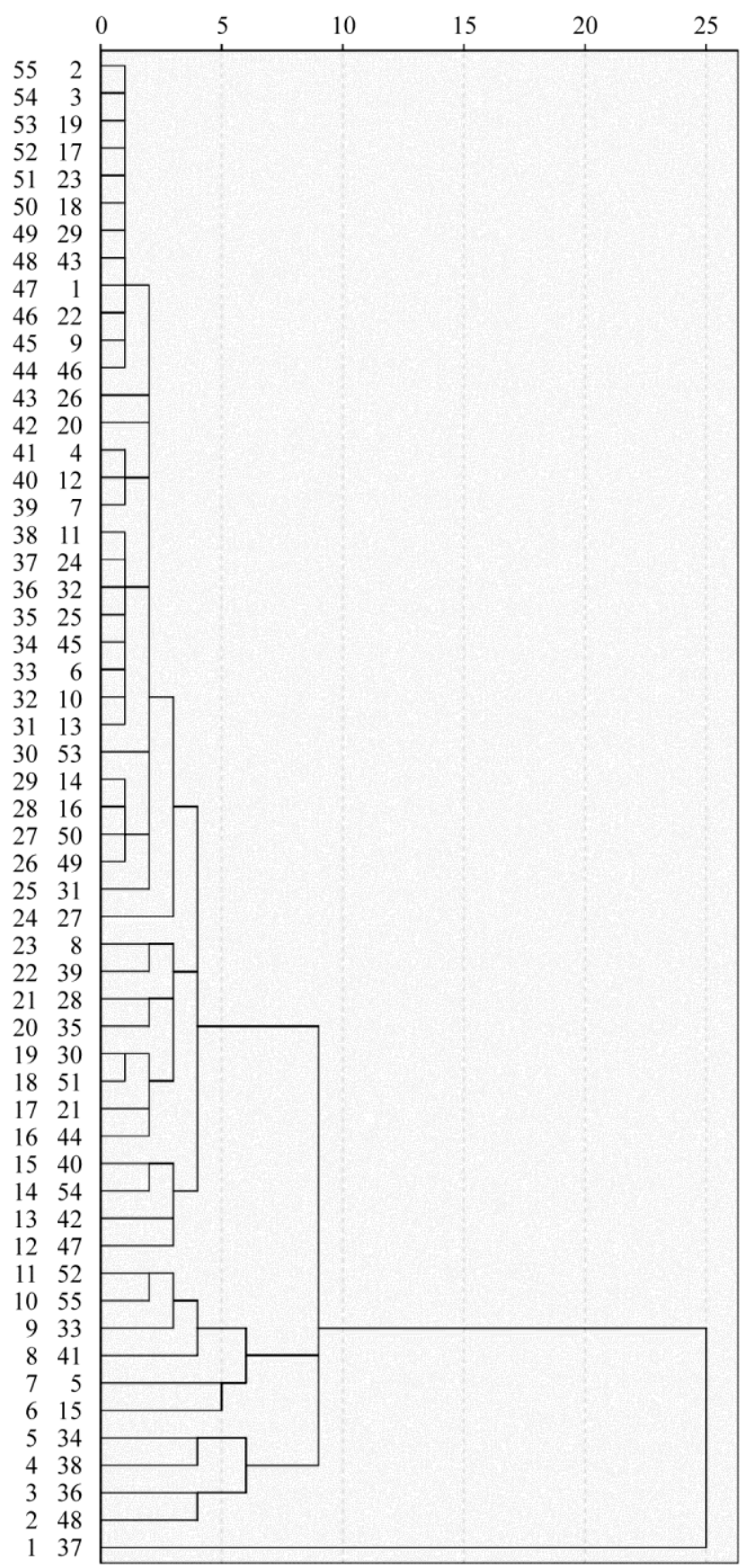


7. ábra. A többdimenziós sálázás eredménye az MTA IX. Osztály táblázatának adatai alapján a harmadik vizsgálatban

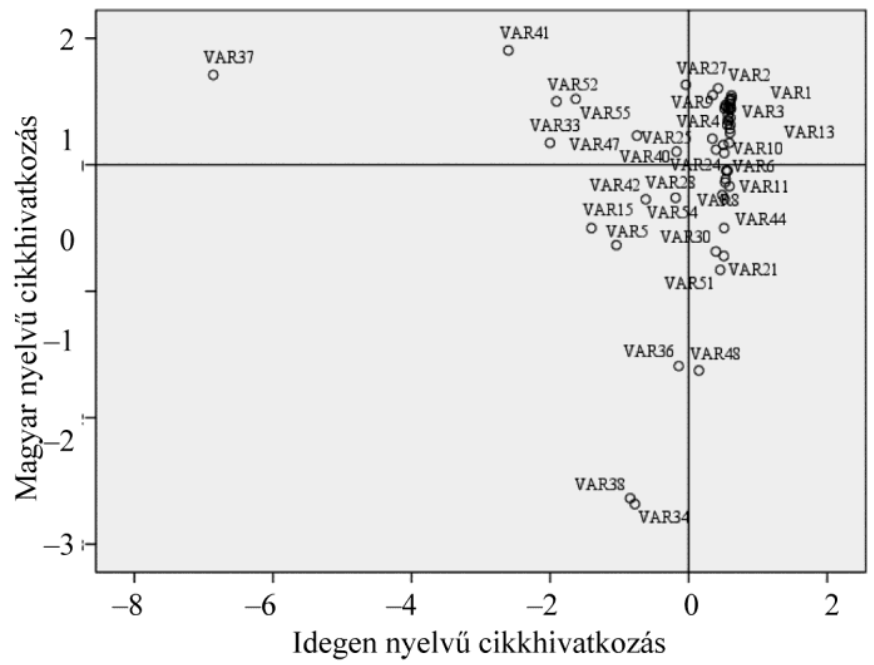

\section{A habilitáltak csoportjainak összevetése a három elemzés alapján}

A következőkben arra teszünk kísérletet, hogy a három vizsgálattal nyert habilitáltak csoportosítását összehasonlítsuk. Ez arra mutat rá, hogy mennyire függnek a változóhalmazainktól a csoportosítások. Azt már megállapítottuk, hogy a klaszteranalízis és a többdimenziós skálázás szinte ugyanazt az eredményt adta. A 10. táblázatban foglaltuk össze a három elemzés eredményeit. Azokat a habilitáltakat vettük figyelembe, akik a klaszteranalízis folyamán lényegesen eltértek a többségtől, vagyis az első vizsgálatból 14, a másodikból 13, míg a harmadik vizsgálatból is 11 habilitáltat. A táblázat tehát azokat a habilitáltakat tartalmazza, akiket „hagymahéjszerüen” le lehet választani a habilitáltak csoportjáról a vizsgálatokban.

Amint a táblázat mutatja, 10 habilitált mindhárom elemzésben a leválasztottak csoportjába került: $5,15,33,34,36,37,38,41,52$ és 55-ös sorszámú. A 48-as számú habilitált két elemzésben volt a hagymahéj része, míg a 6, 8, 11, 27, 42 és 47-es számú habilitált csak egyszer. Ez arra utalhat, hogy a csoportosítás kevéssé érzékeny a választott adatállományra. A csoportosító módszerek (esetünkben klaszterelemzés és többdimenziós skálázás) azonban arra nem adnak választ, hogy mely publikációs mutatók alapján válogathatók le a habilitáltak, és miben térnek el a csoport többi tagjától. 
10. táblázat

\begin{tabular}{|c|c|c|}
\hline \multicolumn{3}{|c|}{$\begin{array}{r}\text { A három vizsgálat lényegesen eltérö csoportjáno } \\
\text { a habilitáltak sorszáma szerint }\end{array}$} \\
\hline 1. elemzés & 2. elemzés & 3. elemzés \\
\hline 5 & 5 & 5 \\
\hline 6 & & \\
\hline 8 & & \\
\hline 11 & & \\
\hline 15 & 15 & 15 \\
\hline 27 & & \\
\hline 33 & 33 & 33 \\
\hline 34 & 34 & 34 \\
\hline 36 & 36 & 36 \\
\hline 37 & 37 & 37 \\
\hline 38 & 38 & 38 \\
\hline 41 & 41 & 41 \\
\hline & 42 & \\
\hline & 47 & \\
\hline & 48 & 48 \\
\hline 52 & 52 & 52 \\
\hline 55 & 55 & 55 \\
\hline
\end{tabular}

Megjegyzés. A vastagított számok a mindhárom vizsgálatban leválasztottak sorszámát jelölik.

\section{5. Összefoglalás és következtetések}

A Budapesti Corvinus Egyetem hét doktori iskolájának minőségbiztosításában meghatározó szerepet játszó Doktori Tanács felismerte, hogy - a PhD-fokozat megszerzéséhez hasonlóan - a habilitált doktori cím kapcsán is szükség van a publikációs minimumkövetelmények explicitté tételére. Annak ellenére, hogy a testület által 2015 tavaszán felkért munkabizottság tagjai jelentős tapasztalatokkal rendelkeztek a tudományos minősítés terén, a feladat - különösen annak algoritmizálása - komoly kihívást jelentett. Első lépésben kézenfekvőnek tünt, hogy a már sikeresen habilitáltak átlagos teljesítményét célszerü alapul venni, de éppen a mủvelt tudományterületek sokfélesége, pontosabban az eltérő publikációs szokások és a habilitált doktori címet szerzettek közötti élettapasztalatok (nevezzük korkülönbségeknek) bonyolul- 
tabb számítások elvégzésére ösztönöztek. A végül három körben lebonyolított vizsgálat egyértelmüen igazolta, hogy a többváltozós matematikai statisztika alkalmas a tudománymetria tárgykörébe sorolható döntéshozói igény kielégítésére. Ugyanakkor tisztán a korábban habilitáltak publikációs teljesítményére épülő matematikai algoritmusok alkalmazása kizárja az Egyetemi Doktori Tanács tagjai által artikulálódó egyéni érdemek és intézményi érdekek érvényesítését, továbbá megnehezíti a folyamatosan és meglehetős dinamizmussal változó technológiai környezet szerepének mérlegelhetőségét (például internetes nemzetközi folyóirat adatbázisok elérhetősége vagy online publikálási lehetőség). Ezt igazolja, hogy számottevő azoknak a már habilitált kollégáknak a száma, akik - miközben szakterületük kiváló képviselöi - a habilitálásukkor nyújtott teljesítményükkel egyetlen, a vizsgálat során alkalmazott számítási módszer alapján kalkulált elvárásnak sem felelnének meg. Ebből következik tehát, hogy a matematika - a megrendelöként fellépő tudományos közösség finomhangolása nélkül - önmagában nem alkalmas a követelményrendszer meghatározására. Így a habilitációs minimumelvárások a matematika eszköztárának hathatós segítségével végső soron csak társadalmi konszenzussal fogadhatók el.

\section{Irodalom}

BEnCZE Gy. [2014]: Hogyan lovagoljunk a tudományos teljesítményen? Magyar Tudomány. 175. évf. 11. sz. 1350-1353. old.

BerÉnYi D. [1995]: Akadémiai doktori cím és egyetemi habilitáció. Magyar Tudomány. 102. évf. 5. sz. 582-584. old.

BRAUN T. [2008]: Szellem a palackból, tudománymetriai értékelések. Magyar Tudomány. 169. évf. 11. sz. 1366-1371. old.

Csaba L. - Szentes T. - Zalai E. [2014]: Tudományos-e a tudománymérés. Megjegyzések a tudománymetria, az impakt faktor és az MTMT használatához. Magyar Tudomány. 175. évf. 4. sz. 442-466. old.

Dobos I. - Michalkó G. - NovÁky E. [2016]: Miért nincs királyi út a habilitáció publikációs követelményeinek meghatározására? Magyar Tudomány. 177. évf. 11. sz. 1379-1390. old.

Füstös L. - Meszéna Gy. - Simonné Mosolygó N. [1986]: A sokváltozós adatelemzés statisztikai módszerei. Akadémiai Kiadó. Budapest.

GLÄNZEL W. [2009]: A tudománymetria hét mítosza - költészet és valóság. Magyar Tudomány. 170. évf. 8. sz. 954-964. old.

GRIMBLY, S. [2002]: Nagy földrajzi felfedezések. Kossuth Kiadó. Budapest.

GYŐRI J. [2002]: A habilitáció szabályozása a közép-európai országokban. Magyar Felsőoktatás. 12. évf. 7. sz. 13-14. old.

Hamza G. [2014]: Az egyetemi autonómia reformjának kérdéséhez. Magyar Tudomány. 175. évf. 2. sz. 130-139. old.

KÁKosy L. - VARGA E. [1970]: Egy évezred a Nilus völgyében: Memphisz az Óbirodalom korában. Gondolat. Budapest.

Statisztikai Szemle, 95. évfolỵam 7. szám 
LANDes, D. [1986]: Az elszabadult Prométheusz: Technológiai változások és ipari fejlödés NyugatEurópában 1750-től napjainkig. Gondolat Kiadó. Budapest.

PAPP Z. [2005]: Az egyetemi oktatók előmeneteli rendszerének problémáiról. Magyar Tudomány. 166. évf. 3. sz. 325-332. old.

PAtKós A. [2003]: Kutatás és egyetem kapcsolata Európában és Magyarországon. Magyar Tudomány. 164. évf. 8. sz. 1025-1034. old.

SAIN M. [1986]: Nincs királyi út! Matematikatörténet. Gondolat Kiadó. Budapest.

SAmuelson, P. - Nordhaus, W. [2012]: Közgazdaságtan. Akadémiai Kiadó. Budapest.

VINKLER P. [2008]: Tudománymetriai kutatások Magyarországon. Magyar Tudomány. 169. évf. 11. sz. 1372-1380. old.

ZALAI E. [2006]: Az MTA doktora címre pályázók habitusvizsgálatának értékelése, 2001-2005. Magyar Tudományos Akadémia, IX. Osztály Gazdaságtudományi Minősítőbizottság. Közgazdasági Szemle. LIII. évf. Április. 380-386. old.

Zsoldos A. [2015]: A tudományos könyv és a tudományos teljesítmény mérése. Magyar Tudomány. 176. évf. 4. sz. 410-415. old.

\section{Summary}

The paper summarizes the results of a work team assigned by the Doctoral Council of the Corvinus University of Budapest in the spring of 2015. In the paper, the authors, who were charged with laying down the minimum scientific requirements for a possible beginning of a habilitation procedure, investigate the scientific results of formerly habilitated and active scholars at the Corvinus University of Budapest. To do so, methods of multivariate statistical analysis such as factor analysis, cluster analysis and multidimensional scaling are used. 